\title{
Does the Choice of Brand Positioning Strategy Matter in the Creation of Brand Love? The Mediating Role of Brand Positioning Effectiveness
}

\section{Saad Shahid*}

\begin{abstract}
To understand how brand love can be created, this study examines the effect of brand positioning strategies (benefit brand positioning strategy, feature brand positioning strategy and surrogate brand positioning strategy) on brand love, by conceptualizing brand positioning effectiveness as a mediator. The proposed conceptual model was empirically studied with the responses of 607 young consumers from private universities in Pakistan. This study finds evidence of complementary mediation of brand positioning effectiveness between brand positioning strategies, and brand love in the context of high street fashion retail brands. For the brand managers, this study implies that the development of an interpersonal consumer-brand bond can be developed by employing benefit brand positioning strategy, surrogate brand positioning strategy and feature brand positioning strategy. This, as a result, also indicates the effectiveness of all three of these brand positioning strategies.
\end{abstract}

Keywords: Brand positioning strategy, brand positioning effectiveness, brand love, high street retail and Pakistan.

JEL Classification: E32, F23, F44, M00, M30, M31, M37

\section{Introduction}

The idea that consumers form partner-like associations with brands is referred to as brand relationships (McAlexander, Shouten, \& Koeing, 2002). Other than brand love, consumer-brand relationship literature also mentions other forms of associations between consumers and brands. These include brand satisfaction (Carroll \& Ahuvia, 2006), brand trust and brand commitment (Chaudhuri \& Holbrook, 2001; Fournier \& Yao, 1997; Sung \& Choi, 2010), brand attachment (Thomson, MacInnis, \& Park, 2005), brand passion (Albert, Merunka, \& Valette-Florence, 2013) and brand connectedness (Escalas, 2004). Amongst the many concepts explaining consumer-brand relationships, relatively, brand love is a new concept in

\footnotetext{
* Assistant Professor, Lahore School of Economics, Lahore, Pakistan.
} 
the marketing research (Unal \& Aydin, 2013). Fournier (1998) was the pioneer who introduced the concept of love which consumers can experience towards a brand, and explained it as a long-term and passionate relationship of a consumer with a particular brand.

Marketers in the fashion retail industry have been struggling to find out which of the three brand positioning strategies (functional brand positioning strategy, benefit brand positioning strategy, and surrogate brand positioning strategy) is more effective in developing a positive perception about a brand in the consumers' minds. As the differentiation based on functional attributes of fashion retail brands gets blurred, the need to develop strong, emotion based consumer-brand relationship becomes more evident. This is so because the reliance of a significant portion of marketing communications is now appealing to emotions and feelings of the consumers (Grisaffe \& Nguyen, 2011). On the basis of empirical evidence, it has been suggested that brand love is a stronger concept when compared with brand commitment and brand satisfaction, when it comes to predicting the word of mouth and brand loyalty associated with a brand. In eventuality, these very factors could be a reason for the reliance on the emotional appeal aspect in marketing communication (Batra, Ahuvia, \& Bagozzi, 2012).

Practitioners, over time, have advocated the importance of brand love in marketing communications (Delgado, Palazón, \& Pelaez, 2017). Roberts (2006) suggested that a brand based on a brand positioning strategy that encourages the development of love-like brand-consumer relationships, is likely to cause emotional damage in a situation where that particular brand is taken away from the consumers. The word 'love' is being used frequently in marketing communications in Pakistan. The studies that have conceptually explained consumer-objects relations (Shimp \& Madden, 1988) have developed a valid and reliable measure of consumer-object love (Batra et al., 2012; Brakus, Schmitt, \& Zarantonello, 2009; Shimp \& Madden, 1988; Whang, Allen, Sahoury, \& Zhang, 2004). Apart from the research stream which explained brand love as consumerobject love, another stream of brand love research has focused on investigating the antecedents of brand love. These include the brand equity (Batra et al., 2012), brand identification and brand trust (Albert et al., 2013; Bergkvist \& Bech-Larsen, 2010), brand satisfaction (Sarkar, 2011; Sarkar, Ponnam, \& Murthy, 2012; Unal \& Aydin, 2013) and hedonic shopping motivations (Carroll \& Ahuvia, 2006). 
Gil and Velazco (2017) have investigated the effect of brand positioning strategies on brand love in the context of personal branding. However, their research lacks the analysis of the comparative effectiveness of the three brand positioning strategies, and brand love. Park, Jaworski and MacInnis (1986) acknowledge that three brand positioning strategies namely; functional brand positioning strategy, experiential brand positioning strategy, and symbolic brand positioning strategy, effectively aid towards fortifying a romantic consumer-brand bond. However, the conceptual framework proposed is restricted to symbolic brand positioning strategy, and its impact on brand love and brand identity. Carrol and Ahuvia (2006) have studied the product level brand positioning strategy, and the brand-level constructs in the context of their relationship with brand love. However, this study was limited to examine feature and brand related positioning. It is important to address the knowledge gap which exists in the relationship between brand love, and the choice of brand positioning strategies adopted by fashion retail brands. This premise is also supported by Delgado et al. (2017), who suggested further research in this area, to understand how the development of an emotional consumer-brand bond is imperative in the blossoming of brand love.

Advertising helps fashion brands set their product apart relative to the competition, if they can successfully make a marketing campaign communicating brand love (Grant, 2016). The identity of the brand is communicated with the help of effective brand positioning (Urde, 1999), therefore, making brand positioning strategies critical for the eventual development of brand love. Any form of consumer- brand attachment can be enhanced with the help of effective marketing communications. This is especially true if brand positioning is based on the emotional aspects of the brand, in which case the consumer is expected to show greater commitment towards the brand (Thomson \& MacInnis, \& Park, 2005). In support of the importance of brand positioning strategies on brand love, Grant (2016) states that the magnitude of the love for a brand is largely caused by the perception communicated by the brand executives. He believes that this is done with the help of effective brand positioning. Two questions addressed in this study are; (1) Is the choice of brand positioning strategy (benefit brand positioning strategy, surrogate brand positioning strategy and feature brand positioning strategy) critical for the creation of brand love?, and (2) Does the overall brand positioning effectiveness (namely; favourability, dissimilarity, uniqueness, credibility and sustainability) have a mediating role between the relationship of brand positioning strategies (benefit brand positioning 
strategy, surrogate brand positioning strategy and feature brand positioning strategy), and brand love?

The above mentioned research questions will be answered in the context of Pakistan's high street fashion retail industry. As the competition in this retail industry gets fiercer, effective brand positioning strategies for fashion brands are needed to create differentiation. Pakistan's economy is ranked as the eleventh largest economy, and is believed to have the potential for high growth rate in the coming future (Punjab Board of Investment and Trade, 2016). The economic turnaround between 2013 and 2016 has encouraged both the local and international fashion retail brands to establish their presence in Pakistan (Ahmed, 2016). Seventy three percent of the total population in Pakistan is under the age of 35 years, the increased demand of fashion retail brands can also be attributed to a greater number of young consumers (Punjab Board of Trade and Investment, 2016).

\section{Theoretical Underpinnings and Hypotheses Development}

The idea that the concept of love does not apply only to humans, but also to brands that have attributes with human-like traits is known as anthropomorphism (Alvarez \& Fournier, 2016). Branding a product by giving it a specific name, (Eskine \& Locander, 2014; Waytz, Heafner, \& Epley, 2014), and describing a brand as if it was a human (Aggarwal \& McGill, 2007; Puzakova, Kwak, \& Rocereto, 2013) aims to change consumers' perception so that they anthropomorphize brands. Websites that use marketing communications based on avatars, and follow social norms such as welcoming and saying goodbye to website visitors are attempting to appeal to those anthropomorphic tendencies (Nowak \& Rauh, 2005). High street fashion retail brands, in particular, rely heavily on effective marketing communications to create a strong interpersonal love between consumers and brands. Marketers use various visuals, verbal and metaphorical tools to activate knowledge of a "human" schema, thereby, enhancing the consumer's tendencies to think of brands in anthropomorphic ways.

The development of a love-like relationship between the consumer and a brand is largely based on the choice of the brand positioning strategy (Fuchs, 2008). If a person treats a brand as a human, then it means that he attributes certain human mental capacities, for example emotions or feelings to that brand; or maybe the person tends to believe that the brand 
has emotions and feelings about the consumer (Waytz, Cacioppo, \& Epley, 2010a; Waytz, Epley, \& Cacioppo, 2010b).

Ahuvia (1993) has studied the concept of love as an object. Whang, Allen, Sahoury and Zhang (2004) have shed light on the concept of loving a product, and Thompson, Rebecca and Roland (2005) have analysed the concept of an emotional consumer-brand bond. But no previous researcher has tested the relationship of brand love with different brand positioning strategies, and brand positioning effectiveness. The motivation for the present research is derived partly from Unal and Aydin (2013) who have proposed that "brand love needs to be studied with elements such as brand positioning, trust and brand image". The present research aims to take this concept a step further, by investigating the relationship of brand positioning strategies, brand love and brand positioning effectiveness in fashion apparel retail brands in Pakistan. Wind and Cardozo (1974) provide support to the objective of the study, by stating that consumerbrand relationships are largely dependent on the choice of brand positioning strategies. In this regard, they believe that one such brandconsumer relationship is brand love, which is the focus of this research.

\subsection{Brand Love}

Recognition of the importance of brand love is a relatively recent marketing phenomenon, and has been shown to influence marketing communications decisions (Batra et al., 2012; Carroll \& Ahuvia, 2006). Fournier (2009) explained "that consumers can think about their relationships with brands in a way that is similar to their relationships with committed partners or best friends". The basis of brand love (i.e. consumers developing emotional relationships with brands based on features, personality and symbolic attributes of brands) is grounded in the theory of brand positioning literature (MacInnis \& Folkes, 2017). Through the phenomenon of humanization of brands, consumers express themselves both personally and socially (Ahuvia, 2015). Since brand love is a concept that is derived from the concept of interpersonal love in psychology ("I love you"), and is applied in a consumption context of a product, therefore it is deemed difficult to understand (Delgado et al., 2017).

Shimp and Madden (1988) viewed the concept of brand love as embedded in the interpersonal theories in psychology. They proposed that love that is interpersonal, and love for a product are similar. Among various theories about brand love, Sternberg and Barnes's (1986) triangular theory of love is a common framework researchers have used to explain 
brand love in the past. Sternberg and Barnes's (1986) theory makes use of a metaphor, to conceptually explain consumer-object love. The metaphor comprises of three components; intimacy ("feelings of closeness, connectedness, and bondedness"), passion ("the drives that leads to romance, physical attraction, sexual consummation, and related phenomena in loving relationships"), and decision/commitment ("Decision is the short term recognition that one loves someone else, whereas commitment is the long term intention to maintain that love").

Rauschnabel and Ahuvia (2014) are credited as the pioneers of the concept of brand anthropomorphism and its effect in the form of brand love; but they complained about the lack of research in the domain of brand love. Empirical findings of the relationship of brand love with other consumer behaviour variables are indeed not extensive, and there is more that needs to be done to understand brand love, conceptually and empirically (Batra et al., 2012). In particular, brands of fashion products are known to possess symbolic meanings, as compared to brands in other product categories (Escalas \& Bettman, 2005). This is due to the ability of fashion brands to convey the identity of the wearers (Hebdige, 1987). There is a need to fill the conceptual, contextual and methodological gaps present in understanding the concept of brand love, which is as an emotional bond that creates a romantic relationship between brands and consumers. It must also be understood that this relationship goes beyond brand satisfaction, brand loyalty and brand trust. The research on these lines inevitably needs to relate brand positioning strategies that eventually lead to brand love. Most of the prior literature in this regard originates from the United States of America (Albert et al., 2013); therefore, a study based on Pakistani fashion retail brands will add value to the existing literature on brand love.

Ahuvia $(1993 ; 2005)$ pioneered the quantitative analysis of brand love, and the consumers' ability to love a brand and their related consumption behaviour. Ahuvia's work revolves around explaining that interpersonal love, and consumer-brand love have more commonalities than differences. For example, the consumers find products attractive, they aspire to have them, long for their consumption, and they feel that a certain brand is a natural fit to their personality. Consumers feel willing to spend their financial resources on a brand because they feel as if it is a part of them. This perspective is in consistency with Aron's theory of selfexpansion as applied to brands (Aron \& Aron, 1986), where closeness to a brand is shown in a Venn diagram depicting the self as an overlap with the brand (MacInnis \& Folkes, 2017). 
Despite the existence of different theoretical perspectives about brand love, there is unanimity with regards to the possibility of the presence of love that consumers can have with a brand, and such brands become an important part of their lives (Ballester, Palazón, \& Muñoz, 2017). Although brand love has emerged as an important consumer-brand relationship construct, there is still a lack of understanding as to how the love relationship between a consumer and a brand is created, fostered, and strengthened by the efforts of marketers. It has been proposed that brand love may be influenced by the effectiveness of brand positioning strategies (e.g., product features, benefits of the product) adopted by the marketers (Batra et al., 2012; Carroll \& Ahuvia, 2006).

\subsection{The Mediating Effect of Brand Positioning Effectiveness}

Brand positioning effectiveness is based on "emphasizing the distinctive characteristics that make a brand different from its competitors, and such characteristics are appealing to the consumer" (Kapferer, 2004). Table 1 summarizes the five dimensions of brand positioning effectiveness, as proposed in the literature.

\section{Table 1: Dimensions of Brand Positioning Effectiveness}

\begin{tabular}{|c|c|c|c|}
\hline Author & Year & $\begin{array}{c}\text { Brand } \\
\text { Positioning } \\
\text { Effectiveness } \\
\text { Dimensions } \\
\end{array}$ & Definition \\
\hline $\begin{array}{l}\text { Sujan and } \\
\text { Bettman }\end{array}$ & 1989 & Dissimilarity & $\begin{array}{l}\text { "How similar or distinct the brand is } \\
\text { perceived to be in comparison with } \\
\text { other brands in the product category" }\end{array}$ \\
\hline $\begin{array}{l}\text { Chaturvedi } \\
\text { and Caroll }\end{array}$ & 1998 & Uniqueness & $\begin{array}{l}\text { "The differentiation that a brand } \\
\text { enjoys in the marketplace vis-à-vis its } \\
\text { competitors by virtue of perceptions } \\
\text { unique to that brand, or other } \\
\text { perceptual brand-specific effects". }\end{array}$ \\
\hline $\begin{array}{l}\text { Mahajan and } \\
\text { Wind }\end{array}$ & 2002 & Favourability & $\begin{array}{l}\text { "Brand must be accompanied with } \\
\text { positive associations; the brand needs } \\
\text { to appeal to the head and/or heart of } \\
\text { consumers". }\end{array}$ \\
\hline $\begin{array}{l}\text { Erdem, } \\
\text { Joffre, and } \\
\text { Anna }\end{array}$ & 2006 & Credibility & $\begin{array}{l}\text { "The believability of the product } \\
\text { position information contained in a } \\
\text { brand, which depends on the } \\
\text { willingness and ability of the firms to } \\
\text { deliver what they promise". }\end{array}$ \\
\hline
\end{tabular}




\begin{tabular}{lll}
\hline Keller $2006 \quad$ Sustainability & $\begin{array}{l}\text { "Brand position which is hard to } \\
\text { attack from competitors, defensible, } \\
\text { and pre-emptive". }\end{array}$ \\
\hline
\end{tabular}

Favourability is considered to be the most primary of all other brand positioning effectiveness dimensions (Dacin \& Daniel, 1994). Favourability also determines whether or not consumers have created favourable associations with the brand (Aaker, Batra, \& Myers, 1992; Dillon, Thomas, Amna, \& Soumen, 2001; Keller, 2003). It is important for the marketers that consumers perceive the brand as favourable (Keller, 2003).

Consumers always have various expectations towards a brand (Keller, Sternthal, \& Tybout, 2003), hence the dissimilarity is driven primarily by whether the brand meets the perceived expectations or not (Punj \& Moon, 2002; Sujan \& Christine, 1987). “Attributes on which a brand has values that are similar to the competitor brands will cause perceived similarity, whereas attributes on which a brand has values that are different from the competitors, will create a perception about the brand as dissimilar" (Bijmolt, Wedel, Pieters, \& Desarbo, 1998; Tversky, 1977). Thus, the overall dissimilarity is about the differences that occur in the shared perceptual space of a brand about competitors' brands (Chaturvedi \& Carroll, 1998).

If the brand is perceived to be unique or niche, a market is created for it, and the brand is not perceived to be a prototypical example in that product category (Sujan \& Bettman, 1989). A brand is only credible if it positions itself as a trustworthy brand relative to competition in the perceptual map of consumers (Dröge \& Darmon, 1987). Credibility has the ability to reduce consumers' feelings of scepticism about a particular brand (Yoo \& Donthu, 2001).

Fuchs (2008) defines brand positioning effectiveness as "the extent to which a brand is perceived to occupy a favourable, dissimilar, unique, and credible position in the minds of (target) consumers". This study, proposes to add sustainability as the fifth crucial dimension to the concept of brand positioning effectiveness. Therefore, this study measures brand positioning effectiveness as a multidimensional construct that can be measured with the help of five dimensions namely; favourability, dissimilarity, uniqueness, credibility and sustainability (Edwards, 2001; Fuchs, 2008; Fuchs \& Diamantopoulos, 2012). Many researchers have emphasized on the concept of sustainability dimension (Jobber, 2004; Keller, Sternthal, \& Tybout, 2003; Kotler, 2003; Pham \& Muthukrishnan, 
2002), however, none have empirically tested sustainability as a fifth dimension of brand positioning effectiveness.

The idea of brand positioning effectiveness, as a mediating variable between brand positioning strategies and consumer behaviour consequences needs to be explored in further detail (Fuchs \& Diamantopoulos, 2010). Thus far, the studies pertaining to brand positioning effectiveness treat it as a dependent variable (Azmat \& Lakhani, 2015; Fuchs, 2008; 2012; Fuchs \& Diamantopoulos, 2010; Sair \& Shoaib, 2012). However, in order to take into account the long-term consequence of the choice of brand positioning strategy, one must take into account the intervening role of brand positioning effectiveness and brand love. This premise assumes that if a brand positioning strategy is effective, only then will it develop a consumer-brand bond of love. Most of the prior studies have determined the relationship of brand positioning effectiveness with consumer buying intentions, purchase interest and consumer brand preference (Alpert \& Michael, 1995; Carpenter, Glazer \& Nakamoto 1994; Kalra \& Goodstein, 1998).

Marketers are often faced with the challenge of identifying the most effective brand positioning strategy (Keller \& Lehmann, 2006; Pham \& Muthukrishnan, 2002;). For example, there is an ongoing debate on whether benefit brand positioning strategy is considered to be more effective than surrogate brand positioning strategy, or vice versa. Lack of attention to this challenge in brand positioning strategy research has been pointed out by Keller and Lehmann (2006). Ideally, a brand positioning strategy should be effective to the extent that it is difficult to imitate (Cravens, 2000; Keller, Sternthal, \& Tybout, 2003). A brand positioning strategy is expected to have the ability to achieve a differential advantage for a prolonged period of time for a particular brand (Czepiel, 1992; De Chernatony, 2006).

It has been posited that there exists a clear and unambiguous relationship between consumer behaviour and marketing communication activities (Wind \& Cardozo, 1974). Marketing communication activities are tools for communicating brand positioning to the target consumers (Lilien \& Arvind, 2003; Lodish, 1986). The most widely studied behavioural consequence of brand positioning effectiveness is the intention to purchase a brand; and it is reported to have a strong positive relationship with certain dimensions of brand positioning effectiveness. These include the favourability, dissimilarity, uniqueness and credibility of a brand (Fuchs, 2008). However, this study 
proposes that the timeliest consumer based consequence of brand positioning is the creation and maintenance of brand love.

\subsection{Relationship Between Benefit Brand Positioning Strategies, Brand Positioning Effectiveness, and Brand Love}

The benefit brand positioning strategy has been conceptually explained by many researchers in two parts; direct benefits brand positioning strategy and indirect benefits brand positioning strategy. Direct benefit brand positioning is viewed as having the following features: it "communicates advantages of (the usage of) a brand; is based on the personal value consumers assign to the features of goods and services; is more closely related to one's self than product attributes; is not directly observable; is functional in nature; it reflects whether a brand works as intended; it is mostly composed of attribute-based benefits and it also refers to problems' solutions and functional needs" (Aaker \& Shansby, 1982; Crawford, 1985; Keller, 1993; Tybout \& Sternthal, 2005; Vriens \& Hofstede, 2000). The indirect benefits brand positioning strategy has been explained as "Benefits that satisfy experiential needs; is based on psychosocial consequences derived by consumers out of the use of the product that have a hedonic or expressive function; it gives consumers an indirect advantage of the consumption of a brand; it gives perception of a self or a social-image benefit" (Crawford, 1985; Gutman, 1982; Keller, 1993; Olson \& Thomas, 1983; Tybout \& Sternthal, 2005; Vriens \& Hofstede, 2000).

The personification of a brand shows the brand as having humanlike benefits, even when the brand perception does not have a human-like shape (Delbaere, McQuarrie, \& Phillips, 2011). The purpose of this is to

give consumers an experience of social and personal benefits. Another way in which the benefit brand positioning strategy can be communicated is through the representation of a brand as fulfilling the role of a human in a social setting (MacInnis \& Folkes, 2017). Brands which are positioned based on associative secondary benefits, such as fulfilling the roles of the "hero", the "caregiver" and the "magician", are reported to be more effective in creating positive perceptions about a particular brand in the minds of the consumers (Mark \& Pearson, 2001). Research findings on the role of benefit brand positioning strategy, and its effectiveness are limited. This has made this area of study an important one for understanding the benefit brand positioning strategy, as it helps consumers by forming an emotional relationship with the brand in a human-like manner (MacInnis \& Folkes, 2017). Therefore, this study hypothesizes in the following 
hypothesis that brand positioning effectiveness mediates the relationship between benefit brand positioning strategy and brand love.

Hypothesis 1: Brand positioning effectiveness mediates the relationship between benefit brand positioning strategy and brand love.

\subsection{Relationship Between Surrogate Brand Positioning Strategy, Brand Positioning Effectiveness and Brand Love}

The surrogate brand positioning strategy is designed to develop the consumers' associations regarding the intangible aspects of a brand. It highlights the symbolic attributes of the brand that allow the consumer to come to their own conclusions regarding the perception about that particular brand (Bridges, Kevin, \& Sanjoy, 2000). Surrogate brand positioning strategy is different from other brand positioning strategies that are based on attributes and benefits, or creation of inferred (secondary) associations. Rather, it refers to the intangible aspects of the brand (Bridges, Kevin, \& Sanjoy, 2000; Crawford, 1985; Friedmann \& Parker, 1987; Keller, 1993).

Marketing communications based on assigning the product with a human name (Eskine \& Locander, 2014; Waytz, Heafner, \& Epley, 2014), describing the product in the first person (Aggarwal \& McGill, 2007; Puzakova et al., 2013), and labelling the brand as having a gender, are reported to increase the tendencies of the consumers to anthropomorphize brands (Chandler \& Schwarz, 2010; Waytz, Heafner, \& Heafner, 2014). Such anthropomorphized effects are an outcome of the surrogate brand positioning strategy. This particular line of research implies that consumers can regard brands as human-like partners in real life, only if a brand's marketing communications are based on surrogacy. Kwak, Puzakova, and Rocereto (2015) investigated the effect of consumers' beliefs that "the brand had a mind" of its own, on consumer's perceptions of the fairness of price changes. The study reported that the more a brand is known to have a mind of its own, the more consumers are likely to perceive the brand as being favourable. And therefore, an inseparable consumerbrand bond of interpersonal love is created (MacInnis \& Folkes, 2017). Surrogate brand positioning strategies can be communicated through visual cues, for instance, by making the brand's physical attributes like that of a human (Hur, Koo \&, Hofmann, 2015), or by representing the brand as an avatar for creating inferred associations (Nowak \& Rauh, 2005). Therefore, this study postulates in the following hypothesis that brand positioning effectiveness mediates the relationship between surrogate brand positioning strategy and brand love. 
Hypothesis 2: Brand positioning effectiveness mediates the relationship between surrogate brand positioning strategy and brand love.

\subsection{Relationship Between Feature Brand Positioning Strategy, Brand Positioning Effectiveness and Brand Love}

The feature brand positioning strategy is conceptually explained in literature as a "brand that highlights the concrete attributes of the brand in order to create a differential advantage. Concrete attributes are characteristics of the brand advantage; these are objectively measurable, mostly tangible; these attributes are also specific to the product category" (Aaker \& Shansby, 1982; Hooley, John, \& Nigel, 2004; Keller, 1993; Olson \& Thomas, 1983; Plummer, 2000; Vriens \& Hofstede, 2000).

Empirical findings show that consumers react more favourably towards brands whose brand positioning is based on features (Aggarwal \& McGill, 2007). Considering that the brand positioning is based on the features of a brand, consumers are highly likely to view the brand as different/ similar to other brands. Research suggests that the feature brand positioning strategy, based on tangible attributes, prompts the inference that the brand has a certain value attached to it (MacInnis \& Folkes, 2017). For example, brands using the feature brand positioning strategy are likely to be more negatively judged (when compared to those that do not employ such features) when the brand is involved in socially deviant behaviour (Puzakova et al., 2013). Building upon extant research, this study proposes that brand positioning effectiveness mediates the effect of the feature brand positioning strategy on brand love. Therefore, it can be hypothesized that;

Hypothesis 3: Brand positioning effectiveness mediates the relationship between feature brand positioning strategy and brand love.

Marketing communications are a tool for communicating brand positioning (Lilien \& Arvind, 2003; Lodish, 1986). Overall, the results of this study are aimed at providing brand managers with empirically-based insights for making strong, brand positioning strategy decisions. Occupying a strategic place in the consumers' minds relative to competition in the market place is not adequate for a brand. Developing, and then maintaining a long-term interpersonal relationship of a brand with the consumer, has to be the ultimate aim of marketers. This study tests whether significant relationships exist between brand positioning strategies, and brand love. Moreover, this study explores the role of brand positioning effectiveness as a mediator between the relationship of three 
different brand positioning strategies, and brand love (see Figure 1). This study, therefore, aims to answer the following research question; Does brand positioning effectiveness mediate the relationship between brand positioning strategies (benefit brand positioning strategy, surrogate brand positioning strategy, feature brand positioning strategy), and brand love?

Figure 1: Conceptual Framework

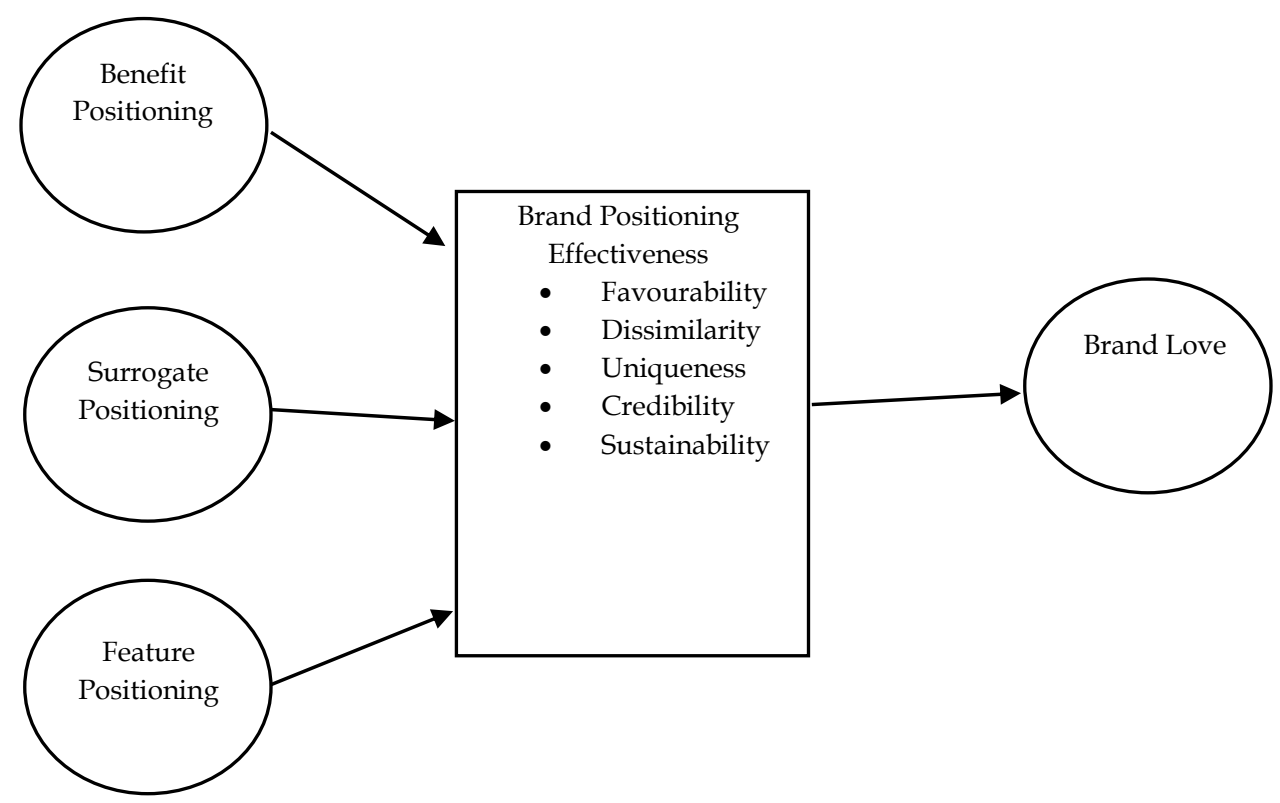

\section{Methodology}

\subsection{Sample}

To test the objectives of the study, a cross-sectional, selfadministered survey methodology was used. It is a regular practice to use surveys for data collection in the discipline of marketing (Crano, Brewer, \& Lac, 2014; Malhotra \& Birks, 2006). The questionnaire was administered amongst the graduate, and postgraduate students of private universities in Pakistan. Prior observational research provides evidence that private university students are the regular shoppers of high street fashion apparel retail brands (Anderson \& Carpenter, 2005). The use of private university students is justified, based on the premise that they have access to the internet so they would not have difficulty in responding to an on-line survey (Boatswain, 2015). Moreover, extant brand positioning studies have most frequently used student samples, therefore, they are equally appropriate for this study (Tepper, William, \& Gary, 2001; Voss, 
Spangenberg, \& Grohmann, 2003). Students' average age was 21 years, out of which, 412 females and 195 males responded to the survey. All the respondents were single and the responses were collected from three main cities; Lahore, Karachi and Islamabad. The respondents had representation from undergraduate, graduate and doctoral programs. Eight private universities were selected randomly from the list of Pakistani universities available on the official website of Higher Education Commission ${ }^{1}$. The questionnaire was distributed among students via e-mail with the help of the registrars in the program offices of eight universities (Wiedmann, Walsh, \& Mitchell, 2001). Out of the questionnaires emailed to students, 607 were received. Table 2 shows the number of survey responses received from the overall eight, randomly selected private universities.

Table 2: Survey Samples Received

\begin{tabular}{|c|c|c|c|c|c|c|c|c|c|}
\hline & Overall & A & B & C & D & E & $F$ & G & $\mathbf{H}$ \\
\hline Responses Received & 607 & 76 & 50 & 122 & 86 & 94 & 22 & 73 & 84 \\
\hline $\begin{array}{l}\text { Data Collection } \\
\text { Method }\end{array}$ & \multicolumn{9}{|c|}{ Online Questionnaire } \\
\hline
\end{tabular}

Note: A, B, C, D, E, F, G and H are names of the universities which are kept anonymous.

\subsection{Instrument}

All the items in the questionnaire are re-worded and adapted from previously published instruments because of their established reliability and validity. The instrument for brand positioning effectiveness, with its five dimensions; dissimilarity, uniqueness, credibility, sustainability, and favourability, was adapted from Fuchs (2008). The scale for all three brand positioning strategies; benefit brand positioning strategy, feature brand positioning strategy and surrogate brand positioning strategy was adapted from Fuchs (2008). The measurement scale originally developed by Fuchs (2008) has been frequently used by many researchers (Azmat \& Lakhani, 2015; Fuchs \& Diamantopoulos, 2010; Sair \& Shoaib, 2014; Smith \& Burns, 2013), therefore, it has an established reliability and validity. The scale comprising of 10 items for brand love was adapted from Ahuvia (2015). The focus of the study is only on high street fashion apparel retail brands which are explained in the Cambridge English Dictionary (2017) as fashion brands that are easily available in shopping malls, and fashion streets in

\footnotetext{
${ }^{1}$ List of private universities in Pakistan is available on the official website of Higher Education Commission (Source: http://www.hec.gov.pk/Ourinstitutes/pages/Default.aspx).
} 
cities for consumers, and are in complete contrast with the custom made fashion designer brands.

\subsection{Data Analysis}

Another concern regarding the bias in results is the non-response bias to questionnaire surveys, resulting as a consequence of missing data, which can lead to biased results of the sample representing a population (Lineback \& Thompson, 2010). Early respondents were compared with late respondents on key demographic indicators (gender, income, marital status, city of residence and education), where late respondents were considered to be non-respondents (Armstrong \& Overton, 1977). This method of measuring non-response bias is called wave analysis, and Armstrong and Overton (1977) named it a linear extrapolation method. It is based on the assumption that early respondents of a survey (W1) are different from late respondents of a survey (W2), and that the late respondents are actually non-respondents. In this study, 413 questionnaires were received in the early wave of the data collection process, and 194 responses were collected in the later wave of the survey data collection. W1 and W2 had a difference of five weeks. W2 responses were generated as a consequence of a reminder e-mail to the program offices of the eight universities.

Questionnaires received in W1 and W2 were compared, based on four demographic variables. These included gender (female or males), marital status (married or single), city of residence (Lahore, Karachi, Islamabad and others) and education (doctoral degree or equivalent, master's degree or equivalent and bachelor's degree or equivalent). Statistical significance was estimated by the Chi-square test in SPSS 22.0. A p-value, less than or equal to 0.05 , was considered statistically significant. Statistically significant differences were not seen in all four demographic indicators, indicating that there was no systematic bias between W1 and W2. No association was found between W1 and W2, based on gender, marital status, city of residence and education $\left(x^{2}=3.17, p=0.20 ; x^{2}=5.61\right.$, $p=0.18 ; x^{2}=3.11, p=0.35$ and $\left.x^{2}=4.76, p=0.25\right)$ respectively. These analyses show that there is a no non-response bias problem in this study, and that the final sample of 607 can be considered an accurate representation of the population.

Most researchers have pointed out the presence of the problem of common method bias in behavioural science (Podsakoff, MacKenzie, Lee, \& Podsakoff, 2003). The common method variance can be defined as 
"variance that is attributable to the measurement method rather than to the construct of interest" (Podsakoff, MacKenzie, Paine, \& Bachrach, 2000). Common method variance can influence the relationships between different variables (Podsakoff et al., 2000). Since the common method bias can affect research findings, therefore, this study used AMOS 22.0 to measure the common method variance.

The common latent factor test was employed as a statistical remedy for the common method bias (Aulakh \& Gencturk, 2000). For this purpose, in order to test the hypothesis that only a single factor can be responsible for the variance in data collected, all items were loaded onto a single factor (Iverson \& Maguire, 2000). This method entails all questions from all of the constructs in the questionnaire into a factor analysis, in order to calculate whether the majority of the variance can be explained by one general factor. The regression weights of all the items were $-.213(21.3 \%)$. The square of the regression weights (common variance) was $36.6 \%$. A single factor explains $36.6 \%$ of the variance in the model. The goodness-of-fit statistics indicators suggested a bad model fit, since these indices value fell outside the commonly accepted cut-off points; CMIN/ DF $=6.71$ (cut-off point, 2 and 5), normed fit index $(\mathrm{NFI})=0.330$, adjusted goodness of fit index $(\mathrm{AGFI})=0.491$, comparative fit index $(\mathrm{CFI})=0.618$, Tucker Lewis Index $(\mathrm{TLI})=0.447$, root mean square error of approximation $($ RMSEA $)=$ 0.142. All the indicators other than CMIN/ DF had a cut-off point of 0.7, and the RMSEA should have been less than 0.10 (Hair, Hult, Ringle, Sarstedt, \& Thiele, 2017).

The Structural Equation Modelling (SEM) in AMOS 22.0 was used to test the model with the maximum likelihood estimation. The first step in structural equation modelling is the confirmatory factor analysis (CFA) (Anderson \& Gerbing, 1988). The second step is to test the fit of the structural model (Schumacker \& Lomax, 2004). The cut-off point for factor loadings of an item is greater than 0.70 , therefore, it is considered to be reliable (Comrey \& Lee, 1992) (see table 3). Also, the uni-dimensionality of all the items was established by the CFA (Anderson \& Gerbing, 1988). "CFA helped determine the fit of the measurement model along with an estimation of the validity and reliability of the constructs" (Shah \& Goldstein, 2006). The CFA was performed for all the constructs used in this study, i.e., the benefit brand positioning strategy, feature brand positioning strategy, surrogate brand positioning strategy, brand positioning effectiveness, and brand love. 
Table 3: Confirmatory Factor Analysis

\begin{tabular}{|c|c|c|c|c|c|}
\hline Factor and Item & F.L.a & Cronbach's Alpha & $\mathbf{C R}^{\mathbf{b}}$ & $\mathrm{AVE}^{\mathrm{c}}$ & $\mathrm{ASV}^{\mathrm{d}}$ \\
\hline Benefit Positioning & & 0.751 & 0.733 & 0.501 & 0.295 \\
\hline BP1 & 0.781 & & & & \\
\hline $\mathrm{BP} 2$ & 0.710 & & & & \\
\hline BP3 & 0.831 & & & & \\
\hline BP4 & 0.776 & & & & \\
\hline BP5 & 0.892 & & & & \\
\hline BP6 & 0.712 & & & & \\
\hline Surrogate Positioning & & 0.762 & 0.762 & 0.545 & 0.312 \\
\hline SP1 & 0.760 & & & & \\
\hline SP2 & 0.699 & & & & \\
\hline SP3 & 0.781 & & & & \\
\hline SP3 & 0.766 & & & & \\
\hline SP3 & 0.800 & & & & \\
\hline Feature Positioning & & 0.727 & 0.798 & 0.517 & 0.215 \\
\hline FP1 & 0.799 & & & & \\
\hline FP2 & 0.751 & & & & \\
\hline FP3 & 0.738 & & & & \\
\hline FP4 & 0.691 & & & & \\
\hline $\begin{array}{l}\text { Brand Positioning } \\
\text { effectiveness }\end{array}$ & 0.712 & 0.791 & 0.733 & 0.641 & 0.185 \\
\hline Dissimilarity & & & & & \\
\hline DSS1 & & & & & \\
\hline DSS2 & & & & & \\
\hline DSS3 & & & & & \\
\hline DSS4 & & & & & \\
\hline Favourability & 0.701 & & & & \\
\hline FAV1 & & & & & \\
\hline FAV2 & & & & & \\
\hline FAV3 & & & & & \\
\hline FAV4 & & & & & \\
\hline Uniqueness & 0.718 & & & & \\
\hline UNQ1 & & & & & \\
\hline UNQ22 & & & & & \\
\hline UNQ3 & & & & & \\
\hline UNQ4 & & & & & \\
\hline Credibility & 0.771 & & & & \\
\hline CRE1 & & & & & \\
\hline CRE2 & & & & & \\
\hline CRE3 & & & & & \\
\hline CRE4 & & & & & \\
\hline CRE5 & & & & & \\
\hline Sustainability & 0.700 & & & & \\
\hline SUS1 & & & & & \\
\hline SUS2 & & & & & \\
\hline SUS3 & & & & & \\
\hline SUS4 & & & & & \\
\hline
\end{tabular}




\begin{tabular}{lccccc}
\hline Factor and Item & F.L.a $^{\mathbf{a}}$ & Cronbach's Alpha & CR $^{\mathbf{b}}$ & AVEc $^{\mathbf{c}}$ & ASVd $^{\mathbf{d}}$ \\
\hline Brand Love & & 0.744 & 0.711 & 0.613 & \\
BL1 & .734 & & & & \\
BL2 & .690 & & & \\
BL3 & .831 & & & \\
BL4 & .777 & & & \\
BL5 & .782 & & & \\
BL6 & .711 & & & \\
BL7 & .791 & & & \\
BL8 & .701 & & & \\
BL9 & .733 & & & \\
BL10 & .776 & & & \\
\hline
\end{tabular}

Goodness-of-fit statistics: CMIN/ DF $=2.56, \mathrm{NFI}=0.711, \mathrm{AGFI}=0.776, \mathrm{CFI}=0.768, \mathrm{TLI}$ $=0.829$, RMSEA $=0.070$

Note: All are statistically significant, $\mathrm{p}<0.05 ; \mathrm{n}=607$

a Standardized Factor Loadings. b Composite Reliability. ${ }^{c}$ Average Variance Extracted. $d$ Average Shared Variance.

\section{Results}

Discriminant and convergent validity of constructs were checked to determine the internal consistency of the constructs, and hence ensured the validity and reliability of the constructs (Tsao, 2014) (see Table 3). The Cronbach's alpha value of the constructs exceeded 0.70, which is a recommended cut-off point for the reliability test in the research domain of social sciences (Nunnally \& Bernstein, 1994). No items of the questionnaire had to be dropped since all the items met the reliability test i.e. factor loadings were above 0.7 on their respective factors. As suggested by Hair et al. (2017), composite reliability (CR) is a superior reliability measure having a recommended cut-off level of 0.70 . Average Variance Extracted (AVE) for the constructs should be greater than 0.5 (Fornell \& Larcker, 1981). This value explains that the constructs have convergent validity, and these constructs have items which reflect the latent constructs. Results indicated that the reliability and convergent validity of the measurement scale is good. Table 4 shows the discriminant validity of the constructs. Ideally, correlations between a construct and all other constructs should be smaller than the square root of the AVE of that construct (Chin, 1998). Numbers in parenthesis on the diagonal show the square root of AVE. For discriminant validity to hold, numbers in each row and column should be smaller than the numbers in the parenthesis in that row and column (Fornell \& Larcker, 1981). The goodness-of-fit indicators indicate a good model fit since they fall within the commonly accepted cutoff points (Hu \& Bentler, 1998); $\mathrm{CMIN} / \mathrm{DF}=2.56, \mathrm{NFI}=0.711$, AGFI $=$ $0.776, \mathrm{CFI}=0.768, \mathrm{TLI}=0.829, \mathrm{RMSEA}=0.07$. 
Table 4: Discriminant Validity

\begin{tabular}{lccccc}
\hline Constructs & BP & SP & FP & BPE & BL \\
\hline BP & $(0.70)$ & & & & \\
SP & $0.42^{* *}$ & $(0.74)$ & & & \\
FP & $0.32^{* *}$ & $0.39^{* *}$ & $(0.72)$ & & \\
BPE & $0.38^{* *}$ & $0.31^{* *}$ & $0.37^{* *}$ & $(0.80)$ & \\
BL & $0.29^{* *}$ & $0.24^{* *}$ & $0.33^{* *}$ & $0.47^{* *}$ & $(0.84)$ \\
\hline
\end{tabular}

**Correlation is significant at the 0.05 level (2-tailed).

Numbers in parenthesis on the diagonal show the square root of AVE. For discriminant validity to hold, numbers in each row and column should be smaller than the numbers in parenthesis in that row and column.

Labels: BF, Benefit positioning; SP, Surrogate positioning; FP, Feature positioning; BPE, Brand positioning effectiveness; BL, Brand love.

In order to test the conceptual model (see figure 1), the research hypotheses were examined using structural model testing. Results of the relationships between benefit brand positioning strategy, feature brand positioning strategy, surrogate brand positioning strategy and brand love are shown in Table 5 . The benefit brand positioning strategy and the surrogate brand positioning strategy are significantly positively related with brand love $\left(\beta=.654^{* *}, \mathrm{p}<.000\right.$ and $\left.\beta=.261^{* *}, \mathrm{p}<.001\right)$, respectively. On the contrary, feature brand positioning strategy does not lead to the creation of brand love $\left(\beta=.413^{* *}, p<.210\right)$. Goodness-of-fit indicators suggested a good model fit since they fall within the commonly accepted cut-off points as shown in Table 5 (Hu \& Bentler, 1998).

Table 5: Coefficients of the Structural Model

\begin{tabular}{lccc}
\hline Independent Variables & Dependent Variables & $\boldsymbol{\beta}^{\mathbf{a}}$ & $\boldsymbol{p}$ \\
\hline $\begin{array}{l}\text { Benefit brand positioning } \\
\text { strategy }\end{array}$ & Brand Love & $0.654^{* *}$ & 0.000 \\
$\begin{array}{l}\text { Surrogate brand positioning } \\
\text { strategy }\end{array}$ & Brand Love & $0.261^{* *}$ & 0.001 \\
$\begin{array}{l}\text { Feature brand positioning } \\
\text { strategy } \\
\quad \text { Goodness-of-fit statistics: CMIN/ DF = 3.28, NFI }=0.732, \text { AGFI }=0.815, \text { TLI }= \\
\quad 0.887, \text { CFI = 0.701, RMSEA }=0.082\end{array}$ & 0.413 & 0.210 \\
\hline
\end{tabular}

aStandardized coefficients are reported.

This study makes use of bootstrapping (3000 subsamples, standardized estimates of the direct and indirect effects, 95\% bias-corrected 
confidence intervals) (Jones, Taylor, \& Bansal, 2008), to measure the mediating effect of brand positioning effectiveness between benefit brand positioning strategy, feature brand positioning strategy, surrogate brand positioning strategy and brand love. "Bootstrapping empirically estimates the sampling distribution of the indirect effect and generates a confidence interval for estimation and hypothesis testing" (Preacher \& Hayes, 2008). Bootstrapping has become the preferred method for estimating indirect effects in the mediation analysis (Preacher \& Hayes, 2008). Graphical representation of the mediation analysis can be seen in three separate structural equation models (M1, M2 and M3) (see figures 2, 3 and 4).

Figure 2: Mediation Effect of Brand Positioning Effectiveness between Benefit Brand Positioning Strategy and Brand love

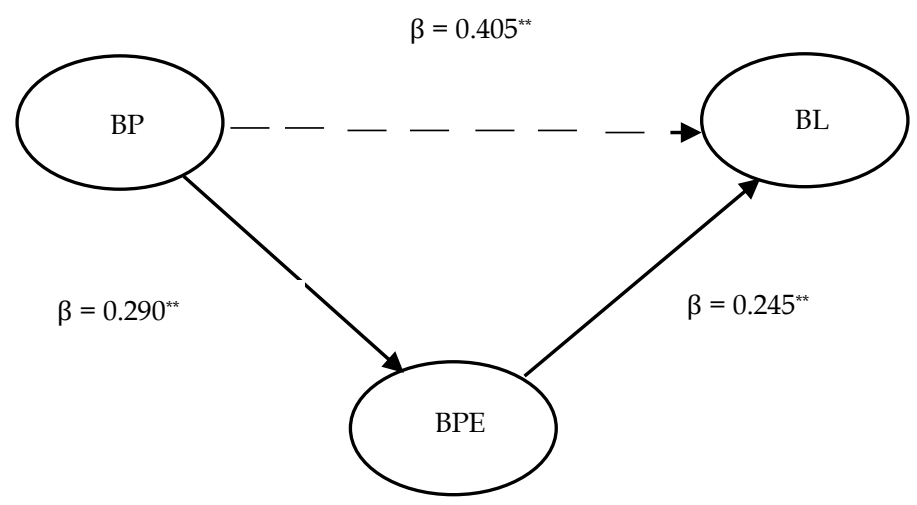

Figure 3: Mediation Effect of Brand Positioning Effectiveness between Surrogate Brand Positioning Strategy and Brand love

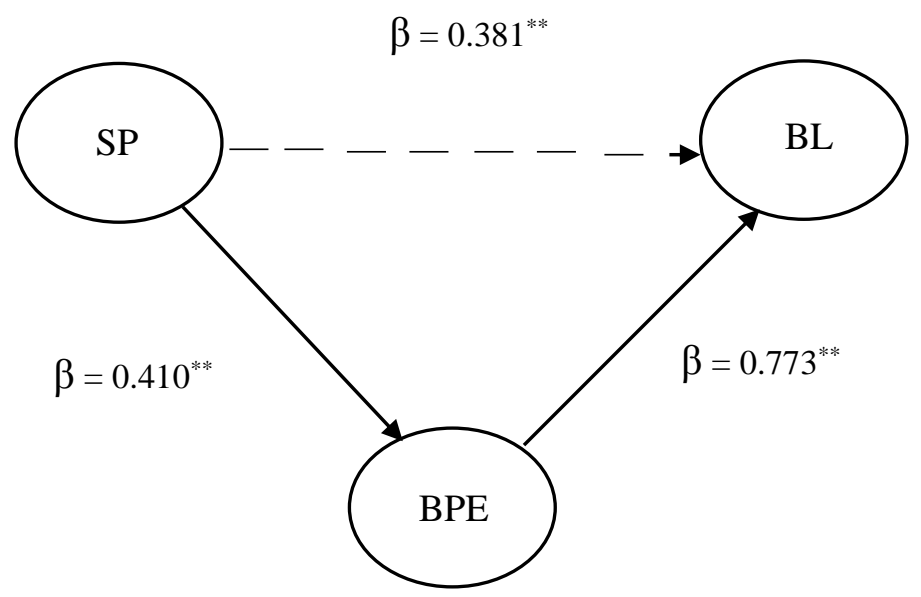




\section{Figure 4: Mediation Effect of Brand Positioning Effectiveness between} Feature Brand Positioning Strategy and Brand love

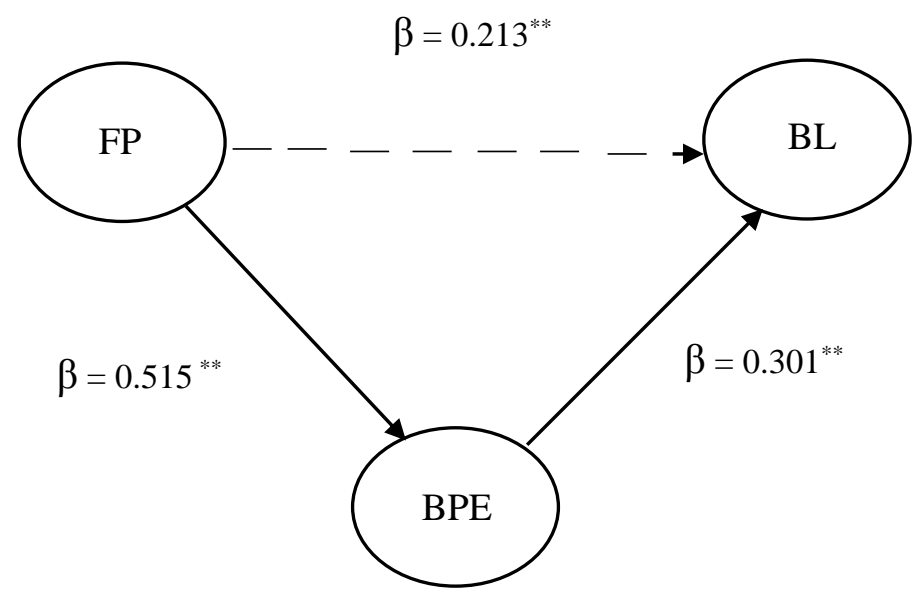

The first test towards mediation analysis is to analyse whether the indirect effect of benefit brand positioning strategy, feature brand positioning strategy, surrogate brand positioning strategy and brand positioning effectiveness on brand love is significant, or not significant (Zhao, Lynch, \& Chen, 2010). The coefficient of indirect effect is significant $\left(\beta=.071^{* *}, p<.000\right)$, as shown in table 6 . The indirect effect being significant confirms that mediation is present (Zhao, Lynch, \& Chen, 2010). Upon adding brand positioning effectiveness as a mediator between the relationship of benefit brand positioning strategy and brand love, the coefficient remains significant $\left(\beta=.405^{* *}, \mathrm{p}<.000\right)$. The coefficients of benefit brand positioning strategy, and brand positioning effectiveness, brand positioning effectiveness and brand love also remain significant ( $\beta$ $\left.=.290^{* *}, \mathrm{p}<.003 ; \beta=.245^{* *}, \mathrm{p}<.001\right)$. Therefore, the mediator is identified to be consistent with the hypothesized conceptual framework, and it can be said that the brand positioning effectiveness complimentarily mediates the relationship between benefit brand positioning effectiveness, and brand love. All the goodness-of-fit statistics for $\mathrm{H}_{1}$ (M1) were within the acceptable range $(\mathrm{CMIN} / \mathrm{DF}=3.01, \mathrm{NFI}=.714, \mathrm{AGFI}=.759, \mathrm{TLI}=.832$, $\mathrm{CFI}=.793, \mathrm{RMSEA}=.077)$. 
Table 6: Results of Mediation Analysis Predicting Brand Love

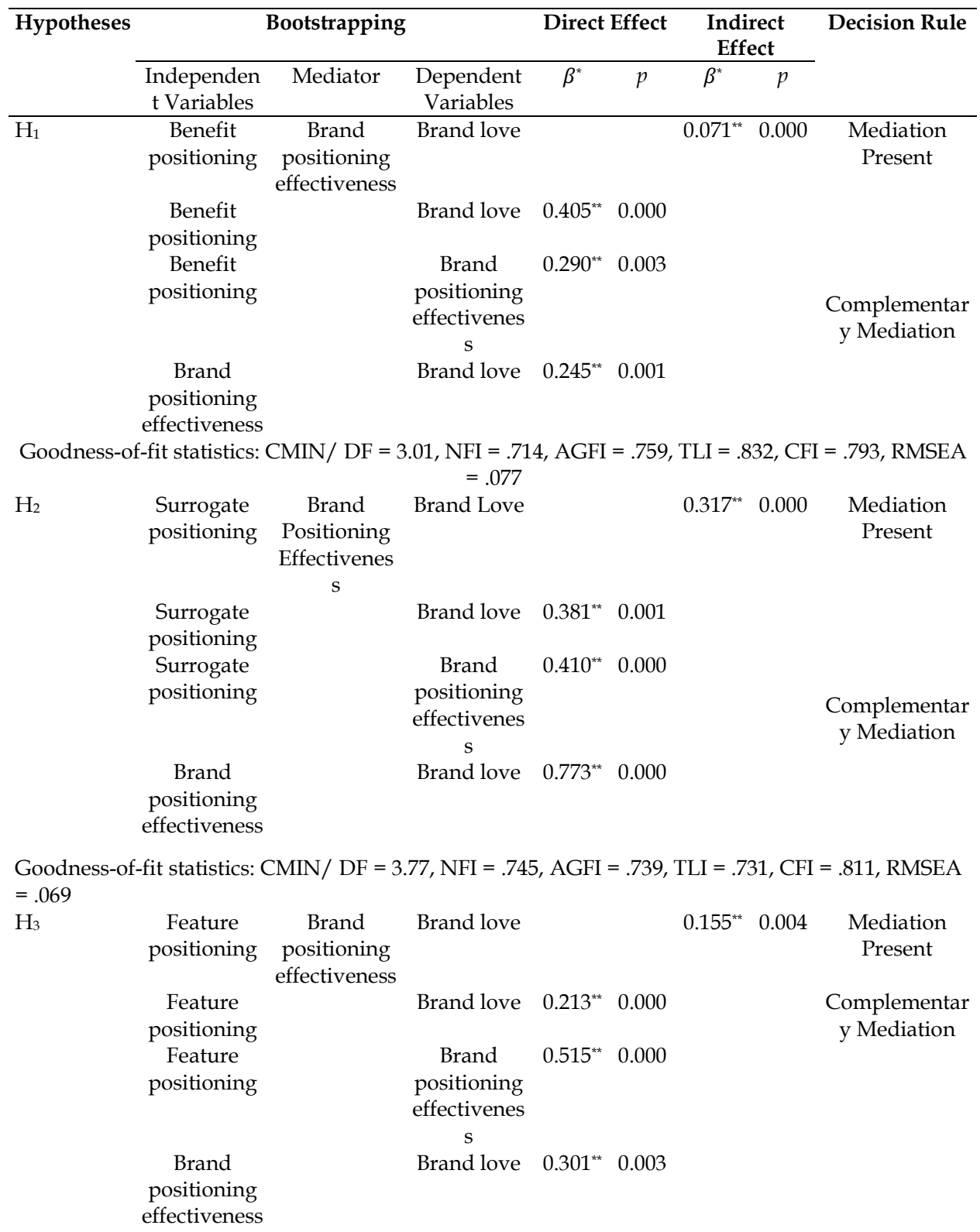

Goodness-of-fit statistics: CMIN/ DF $=2.17, \mathrm{NFI}=0.712, \mathrm{AGFI}=0.881, \mathrm{TLI}=0.791, \mathrm{CFI}=0.913$, RMSEA $=0.070$

${ }^{*}$ Standardized regression co-efficients. 
The coefficient of indirect effect is significant $\left(\beta=.317^{* *}, \mathrm{p}<.000\right)$, as shown in Table 6 . The indirect effect being significant confirms that mediation is indeed present (Zhao, Lynch, \& Chen, 2010). After adding brand positioning effectiveness as a mediator between the relationship of surrogate brand positioning strategy and brand love, the coefficient remains significant $\left(\beta=.381^{* *}, p<.000\right)$. The coefficients of surrogate brand positioning strategy and brand positioning effectiveness, brand positioning effectiveness and brand love also remain significant $\left(\beta=.410^{* *}\right.$, $\left.\mathrm{p}<.000 ; \beta=.773^{* *}, \mathrm{p}<.001\right)$. Therefore, the mediator is identified to be consistent with the hypothesized conceptual framework, and it can be said that brand positioning effectiveness complimentarily mediates the relationship between surrogate brand positioning effectiveness and brand love. For $\mathrm{H}_{2}$ (M2), all the goodness-of-fit statistics were within the acceptable range of values $(\mathrm{CMIN} / \mathrm{DF}=3.77, \mathrm{NFI}=.745, \mathrm{AGFI}=0.739$, $\mathrm{TLI}=.731, \mathrm{CFI}=.811, \mathrm{RMSEA}=.069$ ).

The coefficient of indirect effect was found to be significant $(\beta=$ $\left..155^{* *}, \mathrm{p}<.004\right)$, which confirms that mediation is present. In the presence of brand positioning effectiveness as a mediator between the relationship of feature brand positioning strategy and brand love, it was estimated that the relationship between feature brand positioning strategy and brand love, feature brand positioning strategy and brand positioning effectiveness, brand positioning effectiveness and brand love was found to be significant $\left(\beta=.213^{* *}, p<.000 ; \beta=.515^{* *}, p<.000 ; \beta=.301^{* *}, p<.003\right)$, respectively. Since the direct effect is insignificant, it can be said that the relationship between feature brand positioning strategy, and brand love is mediated by brand positioning effectiveness. This result is consistent with the hypothesized theoretical framework. For $\mathrm{H}_{3}(\mathrm{M} 3)$, all the goodness-offit statistics were within the acceptable range of values $(\mathrm{CMIN} / \mathrm{DF}=2.17$, $\mathrm{NFI}=.712, \mathrm{AGFI}=.881, \mathrm{TLI}=.791, \mathrm{CFI}=.913, \mathrm{RMSEA}=.070)$.

In conclusion, brand positioning effectiveness complementarily mediates the relationship between benefit brand positioning strategy, and brand love; and also complementarily mediates the relationship between surrogate brand positioning strategy and brand love. Benefit brand positioning strategy was found to have a significant direct effect on brand love, and a significant indirect effect on brand love through brand positioning effectiveness. Similarly, surrogate brand positioning strategy was found to have a significant direct effect on brand love, and a significant indirect effect on brand love through brand positioning effectiveness. Feature brand positioning strategy was found to have an insignificant direct effect on brand love, and a significant indirect effect on brand love 
through brand positioning effectiveness. Therefore, brand positioning effectiveness has an indirect-only mediation between the relationship of feature brand positioning strategy and brand love.

\section{Discussion and Managerial Implications}

The findings of this study present evidence that the relationships between benefit brand positioning strategy and brand love, surrogate brand positioning strategy, feature brand positioning strategy and brand love were mediated by brand positioning effectiveness. The intense competition in the high street fashion apparel retail industry underscores the need for the choice of the most effective brand positioning strategy. This ultimately leads to the establishment of an interpersonal consumerbrand bond. The relationship of love between consumers and fashion brands is highly likely to serve as the biggest impediment to brand switching. However, the development of this inseparable bond depends on the choice of brand positioning strategy as well. In this contextual setting, it was found that brand positioning strategies are the starting point of developing a love-like consumer-brand bond, with brand positioning effectiveness acting as a mediator.

Surrogate brand positioning strategy and benefit brand positioning strategy have a positive significant relationship with brand love. Fashion brands whose marketing communications are focused on showing the benefits of product use are likely to create brand love. Similarly, if fashion brands adopt positioning based on symbolic aspects of the fashion brand, it is likely that an inseparable romantic consumer-brand bond will be formed which is the ideal state of association between consumers and brands. Opposing results were found for the feature brand positioning strategy. Fashion brands will not be able to create brand love if their positioning is based on tangible features of the product offering.

The indirect effect indicates that the benefit brand positioning strategy, surrogate brand positioning strategy, feature brand positioning strategy through brand positioning effectiveness, will have an impact on the development of brand love. The results confirm that brand positioning effectiveness acts as a complementary mediator between benefit brand positioning strategy, feature brand positioning strategy and surrogate brand positioning strategy. All three of these aspects play a vital role in creating brand love for fashion retail brands (Pham \& Muthukrishnan, 2002). More importantly, this study validates the crucial role of brand positioning effectiveness. This means that if a brand positioning strategy is not 
implemented effectively then it would not lead to brand love. It compliments past studies from Albert, Merunka and Valette-Florence (2008) in considering the effect of brand positioning effectiveness. This result also verifies that there might be other variables impacting the relationship between the three different brand positioning strategies; and brand love.

This study shows the importance of the choice of brand positioning strategies in creating brand love, and the crucial role of brand positioning effectiveness as a mediator. The benefit brand positioning strategy has a significant and positive impact on brand positioning effectiveness (Schiffman \& Kanuk, 2007). In this study, brand positioning effectiveness was found to have a positive and significant impact on brand love. These findings suggest that marketing efforts should attempt to communicate benefits of the usage of the products of the fashion brand. The brand, through its marketing efforts, must also fulfil all the promises made to the consumers, and advertise itself as a solution to the problem. Surrogate brand positioning strategy was found to have a positive and significant impact on brand positioning effectiveness (Bridges, Kevin, \& Sanjoy, 2000). In this study, brand positioning effectiveness was found to have a positive and significant impact on brand love. Therefore, in the light of these findings, advertising efforts should highlight intangible attributes of the brand, and also promote the secondary associations with the fashion brand. These results suggest that fashion brands should focus all their marketing communications on benefit and surrogate brand positioning strategies i.e. highlighting intangible and symbolic attributes of the brand. The adoption of a strategic choice of benefit brand positioning strategy; and surrogate brand positioning strategy will help develop brand love.

In summary, young consumers of fashion retail brands will form an interpersonal love-like bond with the brand, due to the fashion brand's focus on communicating the benefits of product use. At the same time, benefit brand positioning strategy is likely to lead brand positioning effectiveness. The results for surrogate brand positioning strategy are similar. Consumers of fashion brands will form strong love based consumer-brand bonds if their marketing communications are based on a surrogate brand positioning strategy. Therefore, making surrogate brand positioning strategy should be a significant, but not the only predictor for consumers' brand love for fashion brands.

The direct effect of feature brand positioning strategy is insignificant. Upon adding brand positioning effectiveness as a mediator, both the indirect effect and the direct effect become significant. Therefore, 
it can be assured that the relationship between feature brand positioning strategy, and brand love is complementarily mediated by brand positioning effectiveness. Only if the features of the brands are communicated effectively with the help of marketing communications, will the consumers of fashion retail brands have a great amount of regard for the fashion brand. Consumers seem to show concern for the quality of the fabric, its durability and purposefulness. They need to be sure about the features of the products which fashion brands are offering, and how well they are being communicated to the consumers. This study analysed the complementary mediation of brand positioning effectiveness, implying that feature brand positioning strategy has a significant impact on the effectiveness of brand positioning strategy, which further influences the creation of brand love. In order to be a brand that forms a love-like consumer-brand bond, marketers need to put in a lot of effort to sell the features of their product offerings.

The findings of this study also have critical managerial implications. The positioning strategy of fashion brands should aim towards creating brand love. If consumers feel like they are emotionally and physically attached to a brand, such attachment is likely to initiate brand love. Marketing managers should aim to actively create media mix strategies. These strategies can communicate the various benefits of the consumption of the fashion brand, highlight differentiating product features and promote the symbolic associations of the brand. It is important to note that marketers must understand that the ultimate consumer outcome of brand positioning strategies is the creation of brand love. The findings of this study show that marketers must concentrate on developing a comprehensive understanding of the use of both traditional and alternative marketing mediums. This is so they can effectively communicate observable advantages of fashion products that they are selling i.e. benefit brand positioning strategy. Also, they should consider marketing content to design, and to create consumer associations about the external, symbolic elements, and features of the fashion brand. Marketing managers must take necessary steps in order to not just realise the importance of the choice of brand positioning strategy, but also to acknowledge that brand positioning strategies' effectiveness is equally, if not more, important to the creation of a strong interpersonal consumerbrand bond. Through the mediating effect of brand positioning effectiveness, benefit brand positioning strategy, feature brand positioning strategy and surrogate brand positioning strategy can complementarily create brand love. 


\section{Limitations and Suggestions for Future Research}

This research is not free of limitations. Firstly, it focuses only on the fashion apparel retail industry, and within that industry, the emphasis was on high street fashion retail brands only. Further research in the future can incorporate a more generalizable context, with diversified industry choices, such as kids' clothing, working women's clothing, and maternity fashion clothing (Wilcox, Howell, \& Breivik, 2008). Secondly, brand positioning effectiveness complementarily mediates the relationship between the three brand positioning strategies, and brand love. This gives the researchers a reason to believe that there might be other variables intervening between the relationship of the three different brand positioning strategies, and brand love. Thirdly, this study tests only three brand positioning strategies. Ideally, the future research should test more typologies of brand positioning strategies. Fourthly, qualitative research, such as in-depth interviews with marketing executives of fashion retail brands, might give valuable insights to brand managers and marketers. It might do so in developing a more holistic conceptual framework of interrelationships between brand positioning strategies, brand positioning effectiveness, and brand love. Lastly, a single respondent data collection approach has been used in this study, as only student consumers were approached to respond to the survey questionnaire. Future research may incorporate a multi-level study, where data can be collected at the marketing manager and consumer level as well. 


\section{References}

Aaker, D. A., \& Shansby, G. (1982). Positioning your product. Business Horizons, 25(3), 56-62.

Aaker, D. A., Rajeev, B., \& John, G. M. (1992), Advertising management. London, United Kingdom: Prentice Hall.

Aggarwal, P., \& McGill, A. L. (2007). Is that car smiling at me? Schema congruity as a basis for evaluating anthropomorphized products. Journal of Consumer Research, 34(4), 468-479.

Ahmed, M. (2016). Global retailers eye Pakistani consumers for big money. The News International. Retrieved from https://www.thenews.com.pk/print/109124-Global-retailerseye-Pakistani-consumers-for-big-

Ahuvia, A.C. (1993). I love it! Towards a unifying theory of love across diverse love objects (Unpublished Ph.D. Dissertation). University of Michigan-Dearborn College of Business, USA.

Ahuvia, A. C. (2005). Beyond the extended self: Loved objects and consumers' identity narratives. Journal of Consumer Research, 32(1), 171-184.

Ahuvia, A. C. (2015). Nothing matters more to people than people: Brand meaning and social relationships. In Brand meaning management. Emerald Group Publishing Limited, 12(6) 121-149.

Albert, N., Merunka, D. R., \& Florence-Valette, P. (2008). Conceptualizing and measuring consumers' love towards their brands. Society for Marketing Advances Proceedings, 108-111.

Albert, N., Merunka, D., \& Valette-Florence, P. (2013). Brand passion: Antecedents and consequences. Journal of Business Research, 66(7), 904-909.

Alpert, F. H., \& Michael, A. K. (1995). An empirical investigation of consumer memory, attitude and perceptions toward pioneer and follower brands. Journal of Marketing, 59(October), 34-45.

Alvarez, C., \& Fournier, S. (2016). Consumers' relationships with brands. Current Opinion in Psychology, 10(August), 129-135. 
Anderson, J. C., \& Gerbing, D. W. (1988). Structural equation modeling in practice: A review and recommended two-step approach. Psychological Bulletin, 103(3), 411-423.

Anderson, J. C., \& Carpenter, G. S. (2005), Brand Strategy for Business Markets, in Kellogg on Branding. Jersey City, NJ: John Wiley \& Sons.

Armstrong, J. S., \& Overton, T. S. (1977), Estimating nonresponse bias in mail surveys. Journal of Marketing Research, 14(3), 396-402.

Aron, A., \& Aron, E. N. (1986). Love and the expansion of self: Understanding attraction and satisfaction. New York City, NY: Hemisphere Publishing / Harper \& Row Publishers.

Aulakh, P. S., \& Gencturk, E. F. (2000). International principal-agent relationships-control, governance and performance. Industrial Marketing Management, 29(3), 521-538.

Azmat, M., \& Lakhani, A. S. (2015). Impact of brand positioning strategies on consumer standpoint (A consumer's Perception). Journal of Marketing and Consumer Research, 15, 109-117.

Batra, R., Ahuvia, A., \& Bagozzi, R. P. (2012). Brand love. Journal of Marketing, 76(2), 1-16.

Bergkvist, L., \& Bech-Larsen, T. (2010). Two studies of consequences and actionable antecedents of brand love. Journal of Brand Management, 17(7), 504-518.

Bijmolt, T. H. A., Michel, W., Rik, G. M., \& Wayne S. DeSarbo (1998). Judgments of brand similarity. International Journal of Research in Marketing, 15, 249- 68.

Boatswain, M. L. (2015). Decoy effects in brand positioning (Doctoral dissertation). Kingston University, London, United Kingdom.

Brakus, J. J., Schmitt, B. H., \& Zarantonello, L. (2009). Brand experience: What is it? How is it measured? Does it affect loyalty? Journal of Marketing, 73(3), 52-68.

Bridges, S., Kevin L. K., \& Sanjoy S. (2000). Communication strategies for brand extensions: enhancing perceived fit by establishing explanatory links. Journal of Advertising, 29(4), 1-11. 
Cambridge University Press. (2017). Cambridge dictionaries online. Retrieved from https:// dictionary.cambridge.org/

Carpenter, G. S., Glazer, R., \& Nakamoto, K. (1994), Meaningful brands from meaningless differentiation: The dependence on irrelevant attributes. Journal of Marketing Research, 31(3), 339-50.

Carroll, B. A., \& Ahuvia, A. C. (2006). Some antecedents and outcomes of brand love. Marketing Letters, 17(2), 79-89.

Chandler, J., \& Schwarz, N. (2010). Use does not wear ragged the fabric of friendship: Thinking of objects as alive makes people less willing to replace them. Journal of Consumer Psychology, 20(2), 138-145.

Chaturvedi, A., \& Carroll, J. D. (1998). A perceptual mapping procedure for analysis of proximity data to determine common and unique product-market structures. European Journal of Operational Research, 11(2), 268-84.

Chaudhuri, A., \& Holbrook, M. B. (2001). The chain of effects from brand trust and brand affect to brand performance: the role of brand loyalty. Journal of Marketing, 65(2), 81-93.

Chin, W. W. (1998). The partial least squares approach to structural equation modeling. Modern Methods for Business Research, 295(2), 295-336.

Comrey, A. L., \& Lee, H. B. (1992). Interpretation and application of factor analytic results. Comrey AL, Lee HB. A first course in factor analysis, 2.

Crano, W. D., Brewer, M. B., \& Lac, A. (2014). Principles and methods of social research. New York, NY: Routledge.

Cravens, D. W. (2000). Strategic marketing (6 $6^{\text {th }}$ ed). New York, NY: McGrawHill.

Crawford, C. M. (1985). A new positioning typology. Journal of Product Innovation Management, 2(4), 243-253.

Czepiel, J. A. (1992), Competitive marketing strategy. Jersey City, NJ: Prentice Hall. 
Dacin, P. A., \& Daniel C. S. (1994). The effect of brand portfolio characteristics on consumer evaluations of brand extensions. Journal of Marketing Research, 31(2), 229-242.

De Chernatony, L. (2006). From brand vision to brand evaluation ( $2^{\text {nd }}$ ed). Burlington, Massachusetts, MA: Butterworth- Heinemann.

Delbaere, M., McQuarrie, E. F., \& Phillips, B. J. (2011). Personification in advertising. Journal of Advertising, 40(1), 121-130.

Delgado-Ballester, E., Palazón, M., \& Pelaez-Muñoz, J. (2017). This anthropomorphised brand is so loveable: The role of self-brand integration. Spanish Journal of Marketing-ESIC, 21(5), 216-232.

Dillon, W. R., Thomas J. M., Amna, K., \& Soumen, M. (2001). Understanding what is in a brand rating: a model for assessing brand and attribute effects and their relationship to brand equity. Journal of Marketing Research, 38(November), 415-29.

Dröge, C., \& Darmon, R. Y. (1987). Associative positioning strategies through comparative advertising: attribute versus overall similarity approaches. Journal of Marketing Research, 22(4), 377-88.

Edwards, J. R. (2001). Multidimensional constructs in organizational behavior research: an integrative analytical framework. Organizational Research Methods, 4(2), 144-92.

Erdem, T., Joffre S., \& Ana V. (2006). Brands as signals: A cross-country validation study. Journal of Marketing, 70(January), 34-49.

Escalas, J. E., \& Bettman, J. R. (2005). Self-construal, reference groups, and brand meaning. Journal of Consumer Research, 32(December), 378389.

Escalas, J. E. (2004). Narrative processing: Building consumer connections to brands. Journal of Consumer Psychology, 14(1-2), 168-180.

Eskine, K. J., \& Locander, W. H. (2014). A name you can trust? Personification effects are influenced by beliefs about company values. Psychology and Marketing, 31(1), 48-53. 
Friedmann, R. \& Parker V. L. (1987). Psychological Meaning of Products and Product Positioning. Journal of Product Innovation Management, $4(4), 265-73$.

Fornell, C., \& Larcker, D. F. (1981). Evaluating structural equation models with unobservable variables and measurement error. Journal of Marketing Research, 39-50.

Fournier, S., \& Yao, J. (1997). Reviving brand loyalty: a reconceptualization within the framework of consumer-brand relationships. International Journal of Research in Marketing, 14451-472.

Fournier, S. (1998). Consumers and their brands: Developing relationship theory in Fuchs, C. (2008). Brand Positioning through the Consumers' Lens (Unpublished Doctoral Dissertation) University Wien, Vienna, Austria.

Fuchs, C. (2008). Brand positioning through the consumers' lens (Doctoral Dissertation). University Wien, Vienna, Austria.

Fuchs, C., \& Diamantopoulos, A. (2010). Evaluating the effectiveness of brand positioning strategies from a consumer perspective. European Journal of Marketing, 44(11), pp. 1763-1786.

Fuchs, C., \& Diamantopoulos, A. (2012). Customer-perceived positioning effectiveness: conceptualization, operationalization, and implications for new product managers. Journal of Product Innovation Management, 29(2), 229-244.

Gil, Y. E. T., \& Velazco, M. C. M. (2017). Positioning your personal brand: Consolidate and position your personal branding in a competitive market through love brand. Basic Principles and Introductory Succeeding Success, 5(3), 1-56.

Grant, R. M. (2016). Contemporary strategy analysis: Text and cases edition. Victoria, Australia: John Wiley \& Sons.

Grisaffe, D. B., \& Nguyen, H. P. (2011). Antecedents of emotional attachment to brands. Journal of Business Research, 64(10), 10521059 .

Gutman, J. (1982). A means-end chain model based on consumer categorization processes. The Journal of Marketing, 46(2), 60-72. 
Hair , J. F., Hult, G. T. M., Ringle, C. M., Sarstedt, M., \& Thiele, K. O. (2017). Mirror, mirror on the wall: A comparative evaluation of composite-based structural equation modeling methods. Journal of the Academy of Marketing Science, 45(5), 616-632.

Hebdige, D. (1987). The impossible object: Towards a sociology of the sublime. New Formations, 1(1), 47-76.

Hooley, G. J., John A. S., \& Nigel P. (2004). Marketing strategy and competitive positioning ( $3^{\text {rd }}$ ed.). London, United Kingdom: Prentice Hall.

Hu, L., \& Bentler, P. M., (1998). Fit indices in covariance structure modeling: Sensitivity to under parameterized model misspecification. Psychol Methods, 3(4), 424-453.

Hur, J. D., Koo, M., \& Hofmann, W. (2015). When temptations come alive: How anthropomorphism undermines self-control. Journal of Consumer Research, 42(2), 340-358.

Iverson, R. D., \& Maguire, C. (2000). The relationship between job and life satisfaction: Evidence from a remote mining community. Human Relations, 53, 807-839.

Jobber, D. (2004). Principles and Practice of Marketing (4 ${ }^{\text {th }}$ ed). London, United Kingdom: McGraw-Hill.

Jones, T., Taylor, S. F., Bansal, H. S. (2008). Commitment to a friend, a service provider, or a service company - are they distinctions worth making? Journal of Consumer Behaviour and Marketing Research, 36(4): 473-87.

Kalra, A., \& Goodstein R. C. (1998). The impact of advertising positioning strategies on consumer price sensitivity. Journal of Marketing Research, 35(May), 210-24.

Kapferer, J. (2004). The new strategic brand management (3rd ed). London, United Kingdom: Kogan Page.

Keller, K., L. (1993). Conceptualizing, measuring, and managing customerbased brand equity. The Journal of Marketing, 57(1), 1-22.

Keller, K. L., Sternthal B., \& Tybout, A. (2003). About your brand. Harvard Business Review, 80(September), 81-84. 
Keller, K. L., \& Donald, R. L. (2006). Brands and branding: research findings and future priorities. Marketing Science, 25(6), 740-59.

Kotler, P. (2003). Marketing Management (11 th ed). Jersey City, NJ: Prentice Hall.

Kwak, H., Puzakova, M., \& Rocereto, J. F. (2015). Better not smile at the price: The differential role of brand anthropomorphization on perceived price fairness. Journal of Marketing, 79(4), 56-76.

Lilien, G. L., \& Arvind, R. (2003). Marketing engineering (2nd ed). Jersey City, NJ: Prentice Hall.

Lineback, J. F., \& Thompson, K. J. (2010). Conducting nonresponse bias analysis for business surveys. Joint Statistical Meetings (JSM). Vancouver, Canada.

Lodish, L. M. (1986). The advertising and promotion challenge. New York, NY: Oxford University Press.

MacInnis, D. J., \& Folkes, V. S. (2017). Humanizing brands: When brands seem to be like me, part of me, and in a relationship with me. Journal of Consumer Psychology, 27(3), 355-374.

McAlexander, J. H., Schouten, J. W., \& Koenig, H. F. (2002). Building brand community. Journal of Marketing, 66(1), 38-54.

Mahajan, V., \& Wind, Y. (2002). Got emotional product positioning? Marketing Management 11(3): 36-41.

Malhotra, N., \& Birks, D. (2006). Marketing research: An applied perspective. Harlow, United Kingdom: Prentice Hall.

Mark, M., \& Pearson, C., (2001). The hero and the outlaw: Building extraordinary brands through the power of archetypes. New York, NY: McGraw Hill.

Nowak, K. L., \& Rauh, C. (2005). The influence of the avatar on online perceptions of anthropomorphism, androgyny, credibility, homophily, and attraction. Journal of Computer-Mediated Communication, 11(1), 153-178. 
Nunnally, J. C., \& Bernstein, I. H. (1994). Psychometric theory (3rd ed). New York City, NY: McGraw-Hill

Olson, J. C. \& Thomas, J. R. (1983). Understanding consumers' cognitive structures: implications for advertising strategy. In Advertising and Consumer Psychology. Eds. L. Percy and Arch Woodside, MA: Lexington Books.

Park, C. W., Jaworski, B. J. \& MacInnis, D. J. (1986). Strategic brand conceptimage management. Journal of Marketing 50(4), 135 - 145.

Pham, M. T., \& Muthukrishnan, A. V. (2002). Search and alignment in judgment revisions: Implications for brand positioning. Journal of Marketing Research, 39(1), 18- 30.

Plummer, J. T. (2000). How personality makes a difference. Journal of Advertising Research, 40(6), 79-84.

Podsakoff, P. M., MacKenzie, S. B., Paine, J. B., \& Bachrach, D. G. (2000). Organizational citizenship behavior: A critical review of the theoretical and empirical literature and suggestions for future research. Journal of Management, 26, 513-563.

Podsakoff, P. M., MacKenzie, S. B., Lee, J., \& Podsakoff, N. P. (2003). Common method biases in behavioral research: a critical review of the literature and recommended remedies. Journal of Applied Psychology, 88(5), 879.

Preacher, K. J., \& Hayes, A. F. (2008). Asymptotic and resampling strategies for assessing and comparing indirect effects in multiple mediator models. Behavior research methods, 40(3), 879-891.

Punj, G., \& Moon, J. (2002). Positioning options for achieving brand association: A psychological categorization framework. Journal of Business Research, 55(April), 275-83.

Punjab Board of Investment and Trade. (2016). Retail Sector Report. Lahore, Pakistan: Punjab Board of Investment and Trade. Retrieved from http://www.pbit.gop.pk/system/files/retail_sector_report.pdf

Puzakova, M., Kwak, H., \& Rocereto, J. F. (2013). When humanizing brands goes wrong: The detrimental effect of brand anthropomorphization amid product wrongdoings. Journal of Marketing, 77(3), 81-100. 
Rauschnabel, P. A., \& Ahuvia, A. C. (2014). You're so lovable: Anthropomorphism and brand love. Journal of Brand Management, 21(5), 372-395.

Roberts, K. (2006), The Lovemarks Effect: Winning in the Consumer Revolution, PowerHouse Books, New York, NY.

Sair, S. A., \& Shoaib, M. (2014). Measuring the effectiveness of brand positioning strategies perceived by consumers. Science International, 26(1), 353-361.

Sarkar, A. (2011). Romancing with a brand: a conceptual analysis of romantic consumer-brand relationship. Management $\mathcal{E}$ Marketing, $6(1), 79$.

Sarkar, A., Ponnam, A., \& Murthy, B. K. (2012). Understanding and measuring romantic brand love. Journal of Customer Behaviour, 11(4), 324-347.

Schiffman, L. G., \& Kanuk, L. L. (2007). Consumer behavior. New Jersey, USA: Prentice Hall.

Schumacker R. E., \& Lomax, R. G. (2004). A beginner's guide to structural equation modelling ( $2^{\text {nd }}$ ed). Mahwah. New Jersey, USA: Lawrence Erlbaum.

Shah, R., \& Goldstein, S. M. (2006). Use of structural equation modeling in operations management research: Looking back and forward. Journal of Operations Management, 24(2), 148-169.

Shimp, T. A., \& Madden, T. J. (1988). Consumer-object relations: A Conceptual Framework Based Analogously on Sternberg's Triangular Theory of Love. Advances in consumer research, 15(1), 163168.

Smith, P. W., \& Burns, D. J. (2013). Positioning a brand extension in a retail environment: An exploratory look. Journal of Business and Retail Management Research, 8(1), 20-25.

Sternberg, R. J. (1986). A triangular theory of love. Psychological Review, 93(2), 119-135. 
Sujan, M., \& Christine, D. (1987). Product categorization and inference making: some implications for comparative advertising. Journal of Consumer Research, 14(December), 372-78.

Sujan, M., \& Bettman, J. R. (1989). The effects of brand positioning strategies on consumers' brand and category perceptions: some insights from schema research. Journal of Marketing Research, 26(4), 454-68.

Sung, Y., \& Choi, S. M. (2010). "I won't leave you although you disappoint me": The interplay between satisfaction, investment, and alternatives in determining consumer-brand relationship commitment. Psychology \& Marketing, 27(11), 1050-1073.

Tepper, T. K., William, O., \& Gary L. H. (2001). Consumers' need for uniqueness: Scale development and validation. Journal of Consumer Research, 28(1), 50-66.

Thomson, M., MacInnis, D. J., \& Park, C.W. (2005). The ties that bind: Measuring the strength of consumers' emotional attachments to brands. Journal of Consumer Psychology, 15(1), 531-547.

Thompson, D. V., Rebecca W. H., \& Roland T. R. (2005). Feature fatigue: When product capabilities become too much of a good thing. Journal of Marketing Research, 42(4), 431-42.

Tsao, W. Y. (2014). Enhancing competitive advantages: The contribution of mediator and moderator on stickiness in the line. Journal of Retailing and Consumer Services, 21(6), 933-941.

Tversky, A. (1977). Features of similarity. Psychological Review, 85, 327-352.

Tybout, A. M., \& Sternthal, B. (2005). Brand Positioning. In Kellogg on Branding. Eds. New Jersey: John Wiley \& Sons, 11-26.

Unal, S., \& Aydın, H. (2013). An investigation on the evaluation of the factors affecting brand love. Procedia- Social and Behavioral Sciences, 92, 76-85.

Urde, M. (1999). Brand orientation: A mindset for building brands into strategic resources. Journal of Marketing Management, 15(1-3), 117-133. 
Voss, K. E., Spangenberg, E. R., \& Grohmann, B. (2003). Measuring the hedonic and utilitarian dimensions of consumer attitude. Journal of marketing Research, 40(3), 310-320.

Vriens, M., \& Hofstede, F. (2000). Linking attributes, benefits, and consumer values: A powerful approach to market segmentation, brand positioning, and advertising strategy. Marketing Research, 12(Fall), 5-10.

Waytz, A., Cacioppo, J., \& Epley, N. (2010a). Who sees human? The stability and importance of individual differences in anthropomorphism. Perspectives on Psychological Science, 5(3), 219-232.

Waytz, A., Epley, N., \& Cacioppo, J. T. (2010b). Social cognition unbound: Insights into anthropomorphism and dehumanization. Current Directions in Psychological Science, 19(1), 58-62.

Waytz, A., Heafner, J., \& Epley, N. (2014). The mind in the machine: Anthropomorphism increases trust in an autonomous vehicle. Journal of Experimental Social Psychology, 52(May), 113-117.

Whang, Y. O., Allen, J., Sahoury, N., \& Zhang, H. (2004). Falling in love with a product: The structure of a romantic consumer-product relationship. ACR North American Advances, 31(5), 320-327.

Wiedmann, K. P., Walsh, G., \& Mitchell, V. W. (2001). The Mannmaven: an agent for diffusing market information. Journal of Marketing Communications, 7(4), 195-212.

Wilcox, J. B., Howell, R. D., \& Breivik, E. (2008). Questions about formative measurement. Journal of Business Research, 61, 1219-1228.

Wind, Y., \& Cardozo, R. N. (1974). Industrial market segmentation. Industrial Marketing Management, 3(2), 153-166.

Yoo, B., \& Donthu, N. (2001). Developing and validating a multidimensional consumer-based brand equity scale. Journal of Business Research, 52(April), 1-14.

Zhao, X., Lynch Jr, J. G., \& Chen, Q. (2010). Reconsidering baron and kenny: Myths and truths about mediation analysis. Journal of consumer research, 37(2), 197-206. 